Article

\title{
Advantageous Microwave-Assisted Suzuki Polycondensation for the Synthesis of Aniline-Fluorene Alternate Copolymers as Molecular Model with Solvent Sensing Properties
}

\author{
Rebeca Vázquez-Guilló ${ }^{1}$, Alberto Falco ${ }^{1}$ (D), M. José Martínez-Tomé ${ }^{1}$, C. Reyes Mateo ${ }^{1}$, \\ María Antonia Herrero ${ }^{2,3}$ (D), Ester Vázquez ${ }^{2,3}$ and Ricardo Mallavia 1,* (iD) \\ 1 Instituto de Biología Molecular y Celular, Universidad Miguel Hernández, E-03202 Elche, Spain; \\ rebeca.vazquez@goumh.umh.es (R.V.-G.); alber.falco@umh.es (A.F.); mj.martinez@umh.es (M.J.M.-T.); \\ rmateo@umh.es (C.R.M.) \\ 2 Departamento de Química Inorgánica, Orgánica and Bioquímica, Facultad Ciencias y Tecnologías Químicas, \\ Universidad Castilla La Mancha, E-13071 Ciudad Real, Spain; se.mlcu@orerreh.ainotnaairam (M.A.H.); \\ se.mlcu@zeuqzav.retse (E.V.) \\ 3 Instituto Regional de Investigación Científica Aplicada (IRICA), Edificio Marie Curie, Universidad Castilla \\ La Mancha, E-13071 Ciudad Real, Spain \\ * Correspondence: r.mallavia@umh.es
}

Received: 18 December 2017; Accepted: 20 February 2018; Published: 22 February 2018

\begin{abstract}
Polymerization via Suzuki coupling under microwave $(\mu \mathrm{W})$ irradiation has been studied for the synthesis of poly\{1,4-(2/3-aminobenzene)-alt-2,7-(9,9-dihexylfluorene)\} (PAF), chosen as molecular model. Briefly, $\mu \mathrm{W}$-assisted procedures accelerated by two orders of magnitude the time required when using classical polymerization processes, and the production yield was increased $(>95 \%)$. In contrast, although the sizes of the polymers that were obtained by non-conventional heating reactions were reproducible and adequate for most applications, with this methodology the molecular weight of final polymers were not increased with respect to conventional heating. Asymmetric orientation of the amine group within the monomer and the assignments of each dyad or regioregularity, whose values ranged from $38 \%$ to $95 \%$ with this molecule, were analysed using common NMR spectroscopic data. Additionally, the synthesis of a new cationic polyelectrolyte, poly $\left\{1,4-\left(2 / 3\right.\right.$-aminobenzene)-co-alt-2,7-[9,9'-bis $\left(6^{\prime \prime}-N, N, N\right.$-trimethylammonium-hexyl)fluorene $\left.]\right\}$ dibromide (PAFAm), from poly\{1,4-(2/3-aminobenzene)-co-alt-2,7-[9,9'-bis(6"-bromohexyl)fluorene $]\}$ (PAFBr) by using previously optimized conditions for $\mu \mathrm{W}$-assisted heating procedures was reported. Finally, the characterization of the final products from these batches showed unkown interesting solvatochromic properties of the PAF molecule. The study of the solvatochromism phenomena, which was investigated as a function of the polarity of the solvents, showed a well-defined Lippert correlation, indicating that the emission shift observed in PAF might be due to its interaction with surrounding environment. Proven high sensitivity to changes of its environment makes PAF a promising candidate of sensing applications.
\end{abstract}

Keywords: microwave-assisted; suzuki coupling; poly(fluorene-aniline); solvatochromic effect

\section{Introduction}

Palladium coupling reactions, and, particularly, Suzuki polycondensations enable the synthesis of conjugated copolymers with interesting properties as efficient emitters [1-19]. In general terms, some of the advantages that are related to these reactions are: the need of only a small controlled catalytic amount of palladium catalyst; soft reaction conditions; great tolerance for a variety of functional 
groups; no generation of toxic products; and, no perturbation by the presence of water [20-22]. In particular, unlike direct arylation reactions in which numerous crosslinks occur, the Suzuki coupling reaction allows for obtaining homopolymers and copolymers of fluorene without defects [23-29]. Despite the great development of this reaction in the recent years and its many advantages over other methodologies, the synthesis of conjugated polymers using this type of polycondensation procedures requires further research to reduce their duration and energy consumption, for instance. In this sense, it is necessary to study new models and procedures to deeply understand these processes [30-32].

Synthesis of polyfluorenes, by Suzuki coupling reactions with conventional procedures, usually takes more than $48 \mathrm{~h}$ to produce polymers with convenient molecular weights as shown, for instance, in previous works from our lab $[33,34]$. Reaction times reduction is, therefore, one of the main targets in the optimization of the synthesis conditions [35-39].

Additionally, it is known that the balance between properties, such as the solubility and the effective length of the chains plays an important role in the interaction with other biomolecules and further applications. Thus, controlling the Suzuki polycondensation of novel conjugated polymers with defined properties, such as the effective length of the conjugated polymer chains, with narrow polydispersity (PDI) values and short reaction times, has been an important objective of previous works [21].

For this purpose, new sources of energy may open new opportunities. In recent years, the application of microwaves $(\mu \mathrm{W})$ in organic synthesis has grown exponentially mainly due to drastic reaction time reductions [40-42], greater control of the reaction conditions [43,44] and improvement of the reproducibility [45], and, in many cases, increase of the reaction yields [46]. Currently, besides its use for the synthesis of simple organic molecules, the application of $\mu \mathrm{Ws}$ in polymerization reactions is increasing [47-49]. In particular, the production of conjugated polymers by $\mu W$-assisted coupling reactions is becoming more popular, mainly because it shows a clear economic advantage over conventional heating [48]. For example, the polymerization that is achieved via Suzuki coupling by employing a $\mu \mathrm{W}$-assisted process for the synthesis of poly(9,9-dihexylfluorene) reduced to $15 \mathrm{~min}$ of the reaction time required, once the conditions were optimized [30].

Consequently, the emergence of a new low-cost and quick process conforms an interesting scenario to prepare new copolymers à la carte. Furthermore, post-modifications with the adequate associated functionalities play an important role in the design of new conjugated polymers with applications in cross-disciplinary areas, such as chemistry, material sciences, or biological sciences. In this sense, one of the most common functionalization strategy is the addition of a charged group (either cationic or anionic) within their side-chains in order to obtain conjugated polyelectrolytes (CPEs). Moreover, it is also possible to obtain polyelectrolytes by incorporating pyridinium salts in the polymer backbone due to the reactivity of the amino group and its high donor effect [50].

Thus, in the present work, some aspects governing the order of the monomers in the polymer during the synthesis process have been also studied; in particular, the appearance in the process of an asymmetric monomer, which produces asymmetry in the polymer backbone. The orientation adopted by the asymmetric monomer defines the regioregularity (RR) of the final polymer. The degree of RR informs about the proportion of HT/TH (head to tail or tail to head) dyads when compared to $\mathrm{HH}$ (head to head) and TT (tail to tail) dyads may be tested. A common example of non-regiosymmetic conjugated polymer is poly(3-hexylthiohene-2,5-diyl) ( $\mathrm{P3HT}$ ), in which the reactivity of the asymmetric monomer generates non-equivalent dyads that can be quantified by ${ }^{1} \mathrm{H}$ NMR [51]. Assignments of these dyads in copolymers based on fluorene and aniline unities were proposed by Yamaguchi et al. [50,52]. Based on these assumptions, we tried to understand the processes involved in the copolymerization of commercial diboronate 9,9-dihexylfluorene and an asymmetric monomer, 2,5-dibromoaniline, via Suzuki coupling using microwave irradiation. In other words, the generation of poly[1,4-(2/3-aminobenzene)-alt2,7-(9,9-dihexylfluorene)] (PAF), as the new asymmetric model is proposed here to optimize the parameters appointed before by using non-conventional heating. In this work, this procedure has been also used 
to develop a synthetic route in the preparation of a novel trimethylammonium polyelectrolyte based on diboronate 9,9-di(6-bromohexyl)fluorene and 2,5-dibromoaniline as precursor monomers (Figure 1).

Finally, in addition to the mentioned-above alternative synthesis procedure, the photophysical properties of PAF have been characterized, showing that this polymer displays an interesting solvatochromic effect on its emission profile that can extend the potential applications of this kind of CPEs.
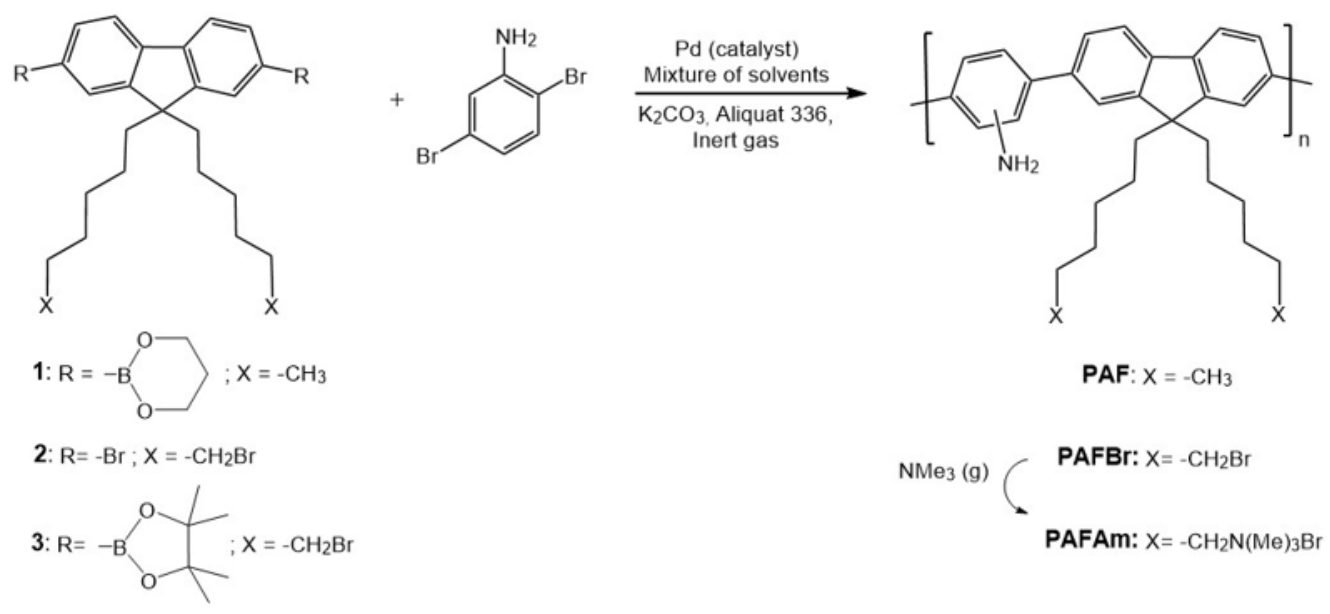

Figure 1. Suzuki coupling of poly-\{1,4-(2/3-amino)benzene-co-alt-[9,9-bis(6'-X-hexyl)-2,7-fluorene]\} derivatives (PAF, $\mathrm{X}=-\mathrm{CH}_{3} ; \mathbf{P A F B r}, \mathrm{X}=-\mathrm{CH}_{2} \mathrm{Br}$ and PAFAm, $\mathrm{X}=-\mathrm{CH}_{2} \mathrm{NMe}_{3} \mathrm{Br}$ ).

\section{Materials and Methods}

\subsection{Materials}

All of the solvents used for chemical reactions were HPLC grade. 2,5-Dibromoaniline, 9,9dihexylfluorene-2,7-diboronic acid bis(1,3-propanediol)ester (1), trioctylmethylammonium chloride (Aliquat 366), tetrakis (triphenylphosphane) palladium $(0)\left[\mathrm{Pd}\left(\mathrm{PPh}_{3}\right)_{4}\right], 4$-[bis(2-methyl-2- propanyl) phosphane]-N,N-dimethylanilinedichloropalladium(2+) $\left[\mathrm{Pd}(\mathrm{Amphos})_{2} \mathrm{Cl}_{2}\right]$ and dichloro $\left[1,1^{\prime}\right.$-bis(diphenylphosphanyl)ferrocene]palladium(2+) cis-[ $\left.\mathrm{PdCl}_{2} \mathrm{dppf}\right]$ were obtained from Sigma-Aldrich $\mathrm{Co}$. (Madrid, Spain).

\subsection{Instrumentation}

Microwave equipment. $\mu \mathrm{W}$-assisted polymerizations were performed by using a CEM Discover reactor in $10 \mathrm{~mL}$ standard Pyrex vessels. The temperature and power was monitored during the process with a calibrated infrared temperature control and pressure sensors. The rest of the parameters were selected and modified, as described in corresponding results section for optimization purposes.

Size Exclusion Chromatography (SEC). SEC analysis was carried out on Shimadzu LC-20AD (Shimadzu, Kyoto, Japan) with an index refraction detector RID-10A (Shimadzu, Kyoto, Japan) and an Evaporative Light Scattering Detector ELSD 3300 (Alltech Associates Inc., Deerfield, IL, USA). SEC analysis of $20 \mu \mathrm{L}$ of samples were injected in a column Plgel $5 \mu \mathrm{m}$ MIXED-C; $2 \times(300 \times 7.5 \mathrm{~mm}$ i.d.) from Polymer Laboratories Ltd. (Salop, UK). Samples around $3-5 \mathrm{mg} / \mathrm{mL}$ in THF (as eluent) and filtered through nylon 0.45 micron membranes. SEC data were initially calibrated using Polymer Laboratories EasiCal Polystyrene (PS) standards.

Nuclear Magnetic Resonance and Fourier Transform Infrared Spectroscopy. ${ }^{1} \mathrm{H}$ and ${ }^{13} \mathrm{C}$ NMR spectra were recorded on a Bruker AVANCE 500 spectrometer (Bruker, Ettlingen, Germany), with tetramethylsilane as an internal reference. Processing of spectra was done using TopSpin 3.2 (Bruker, Rheinstetten, Germany). FTIR spectra were obtained using Bruker IFS66s model spectrometer (Bruker, Karlsruhe, Germany) with samples prepared as $\mathrm{KBr}$ pellets. 
Absorption and Fluorescence Measurements. Absorption spectra of the polymers were recorded in different solvents using a Shimadzu 1673 spectrophotometer (Shimadzu, Kyoto, Japan). Emission spectra were recorded in a PTI QuantaMaster-4 spectrofluorometer (Photon Technology International, Lawrenceville, GA, USA) at $90^{\circ}$ detection angles. Excitation and emission wavelengths are autocalibrated and selected by means of a computer-controlled FeliX32TM Software package (Photon Technology International, Lawrenceville, GA, USA). Corrected steady state fluorescence emission was performed using low absorption solutions.

Thermal and Thermogravimetric analysis. Thermal analyses were performed using differential scanning calorimetry (DSC) in a Perkin Elmer Pyris model 6 apparatus. Quantities of 2-4 mg of samples were scanned for a range of temperatures from 30 to $300{ }^{\circ} \mathrm{C}$ under nitrogen atmosphere at $20^{\circ} \mathrm{C} / \mathrm{min}$ rate (three heating/cooling cycles). Glass transition temperature ( $\mathrm{Tg}$ ) was recorded on the second heating curve. Thermogravimetric analyses (TGA) were performed by using a TGA Q50 (TA Instruments, New Castle, DE, USA) and data was recorded under nitrogen atmosphere by equilibrating at $100{ }^{\circ} \mathrm{C}$, followed by a slope increasing at $10^{\circ} \mathrm{C} / \mathrm{min}$ up to $800{ }^{\circ} \mathrm{C}$.

\subsection{Synthesis and Characterization}

Monomer Synthesis. 2,7-Dibromo-9,9'-bis(6"-bromohexyl)fluorene (2) and bis[9,9'-bis(6"-bromohexyl) fluorenyl]-4,5,5,5-tetramethyl[1.3.2] dioxaborolane (3) were obtained according to previous procedures [53].

General Polymerization. In a round-bottom flask or $\mu \mathrm{W}$ reactor vessel, for conventional or $\mu \mathrm{W}$-assisted heating procedures, respectively, containing a magnetic stir bar, $0.5 \mathrm{mmol}$ of each monomer and the corresponding catalyst percentage (which varied depending on the reaction) were added in the presence of $2 \mathrm{~mL}$ of potassium carbonate $(2.5 \mathrm{M})$ and dissolved in a mixture of solvent (either toluene/water or $\mathrm{THF}$ /water, depending on the reaction) and one drop of Aliquat 366. Each mixture was stirred and degassed under argon atmosphere during the polymerization processes. Then, the solvent was evaporated and the residue was dissolved in chloroform and re-precipitated in methanol twice. Finally, the polymer was dried under vacuum at $40^{\circ} \mathrm{C}$, obtaining a light-brown or beige solid.

Poly[1,4-(2/3-aminobenzene)-co-alt-2,7-(9,9'-dihexylfluorene)] (PAF). Equimolar monomers 2,5dibromoaniline and 9,9-dihexylfluorene-2,7-diboronic acid bis(1,3-propanediol)ester (1).

${ }^{1} \mathrm{H} \mathrm{NMR}\left(500 \mathrm{MHz}, \mathrm{CDCl}_{3}, \mathrm{ppm}\right): \delta=7.86-7.60$ (br m, 4H, Ar), 7.54 (br s, 2H, Ar), 7.38-7.33 (br d, $1 \mathrm{H}, \mathrm{Ar}), 7.19-7.21$ (br d, 1H, Ar), 7.13 (br s,1H, Ar), 4.24-3.89 (br s, 2H, $\left.\mathrm{NH}_{2}\right), 2.05\left(\mathrm{~m}, 4 \mathrm{H}, \mathrm{CH}_{2}(1)\right.$ ), 1.20-1.05 (m, 12H, $\mathrm{CH}_{2}\left(2,4\right.$ and 5)) and 0.85-0.70 (br m, 10H, $\mathrm{CH}_{2}(3)$ and $\left.\mathrm{CH}_{3}\right)$, (see Figures S1-S3).

${ }^{13} \mathrm{C} \mathrm{NMR}\left(125 \mathrm{MHz}, \mathrm{CDCl}_{3}, \mathrm{ppm}\right): \delta=14.2\left(\mathrm{CH}_{3}\right), 22.7\left(\mathrm{CH}_{2}(2)\right), 24.1\left(\mathrm{CH}_{2}(3)\right), 29.9\left(\mathrm{CH}_{2}(5)\right)$, 31.7 $\left(\mathrm{CH}_{2}(4)\right), 40.5\left(\mathrm{CH}_{2}(1)\right), 55.4$ (C Fluorene), $114.5\left(\mathrm{CH}_{\mathrm{Ar}}\right), 118.0\left(\mathrm{CH}_{\mathrm{Ar}}\right), 120.1\left(\mathrm{CH}_{\mathrm{Ar}}\right), 120.2\left(\mathrm{CH}_{\mathrm{Ar}}\right)$, 121.7 $\left(\mathrm{CH}_{\mathrm{Ar}}\right), 123.8\left(\mathrm{CH}_{\mathrm{Ar}}\right), 126.1\left(\mathrm{CH}_{\mathrm{Ar}}\right), 127.3\left(\mathrm{CH}_{\mathrm{Ar}}\right), 127.9\left(\mathrm{CH}_{\mathrm{Ar}}\right), 131.1\left(\mathrm{CH}_{\mathrm{Ar}}\right), 132.5\left(\mathrm{C}_{\mathrm{Ar}}\right), 138.0\left(\mathrm{C}_{\mathrm{Ar}}\right)$, $140.0\left(\mathrm{C}_{\mathrm{Ar}}\right), 141.0\left(\mathrm{C}_{\mathrm{Ar}}\right), 142.2\left(\mathrm{C}_{\mathrm{Ar}}\right), 144.1\left(\mathrm{C}_{\mathrm{Ar}}\right), 151.7\left(\mathrm{C}_{\mathrm{Ar}}\right)$ and $151.9\left(\mathrm{C}_{\mathrm{Ar}}\right)$, (see Figures S4-S6).

IR (KBr disc, $\left.\mathrm{cm}^{-1}\right)$ : 3462, $3380\left(\mathrm{NH}_{2}\right), 3026,2925,2852,1610(\mathrm{NH}), 1460,1307,1246,809,754,696$ and $546 \mathrm{~cm}^{-1}$.

Poly\{1,4-(2/3-aminobenzene)-co-alt-2,7-[9,9'-bis(6"-bromohexyl)fluorene]\} (PAFBr). Equimolar monomers 2,5-dibromoaniline and bis[9,9'-bis(6"-bromohexyl)fluorenyl]-4,5,5,5-tetramethyl[1.3.2]-dioxaborolane (3), using the best non-conventional conditions of PAF, yield a beige solid $86 \%$ SEC (THF, and PS standards): Mw: $5825 \mathrm{~g} / \mathrm{mol}$; PDI: 2.0 .

${ }^{1} \mathrm{H}$ NMR (500 MHz, $\mathrm{CDCl}_{3}, \mathrm{ppm}$ ): $\delta$ = 7.87-7.56 (br m, 4H, Ar), 7.51 (br s, 2H, Ar), 7.38-7.33 (br d, $1 \mathrm{H}, \mathrm{Ar}$ ), 7.21-7.02 (br s, 2H, Ar), 4.24-3.89 (br s, $\left.2 \mathrm{H}, \mathrm{NH}_{2}\right), 3.27$ (br t, $\left.4 \mathrm{H}, \mathrm{CH}_{2}-\mathrm{Br}\right), 2.04\left(\mathrm{~m}, 4 \mathrm{H}, \mathrm{CH}_{2}(1)\right.$ ), $1.66\left(\mathrm{br} \mathrm{s}, 4 \mathrm{H}, \mathrm{CH}_{2}(5)\right), 1.32-1.05\left(\mathrm{~m}, 8 \mathrm{H}, \mathrm{CH}_{2}(3\right.$ and 4$)$ ) and $0.90-0.60\left(\mathrm{~m}, 4 \mathrm{H}, \mathrm{CH}_{2}(2)\right)$, (see Figure $\mathrm{S} 7$ ).

${ }^{13} \mathrm{C} \mathrm{NMR}\left(125 \mathrm{MHz}, \mathrm{CDCl}_{3}, \mathrm{ppm}\right): \delta=23.9\left(\mathrm{CH}_{2}(2)\right), 25.1\left(\mathrm{CH}_{2}(3)\right), 29.4\left(\mathrm{CH}_{2}(5)\right), 32.9\left(\mathrm{CH}_{2}(4)\right)$, $34.1\left(\mathrm{CH}_{2}-\mathrm{Br}\right), 40.3\left(\mathrm{CH}_{2}(1)\right), 55.3$ (C Fluorene), $114.5\left(\mathrm{CH}_{\mathrm{Ar}}\right), 118.6\left(\mathrm{CH}_{\mathrm{Ar}}\right), 120.4\left(\mathrm{CH}_{\mathrm{Ar}}\right), 120.6\left(\mathrm{CH}_{\mathrm{Ar}}\right)$, $121.8\left(\mathrm{CH}_{\mathrm{Ar}}\right), 123.9\left(\mathrm{CH}_{\mathrm{Ar}}\right), 126.2\left(\mathrm{CH}_{\mathrm{Ar}}\right), 127.4\left(\mathrm{CH}_{\mathrm{Ar}}\right), 128.9\left(\mathrm{CH}_{\mathrm{Ar}}\right), 131.2\left(\mathrm{C}_{\mathrm{Ar}}\right), 138.1\left(\mathrm{C}_{\mathrm{Ar}}\right)$, $140.0\left(\mathrm{C}_{\mathrm{Ar}}\right), 140.4\left(\mathrm{C}_{\mathrm{Ar}}\right), 143.9\left(\mathrm{C}_{\mathrm{Ar}}\right), 144.1\left(\mathrm{C}_{\mathrm{Ar}}\right)$ and $151.4\left(\mathrm{C}_{\mathrm{Ar}}\right)$, (see Figure $\left.\mathrm{S} 8\right)$.

IR (KBr disc, $\left.\mathrm{cm}^{-1}\right)$ : 3450, $3378\left(\mathrm{NH}_{2}\right), 2928,2853,1610(\mathrm{NH}), 1556,1461,1352,1256,1145,809$, $755,695,642\left(-\mathrm{CH}_{2}-\mathrm{Br}\right)$ and $557 \mathrm{~cm}^{-1}$. 
Poly\{1,4-(2/3-aminobenzene)-co-alt-2,7-[9,9'-bis(6"-N,N,N-trimethylammoniumhexyl)fluorene $]\}$ dibromide (PAFAm). Quaternization of PAFBr by treatment with trimethylammine, following previous reported studies in our lab, yield $80 \%$ [54].

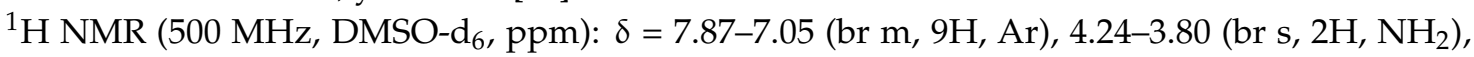
3.21 (br s, $4 \mathrm{H}, \mathrm{CH}_{2}-\mathrm{N}$ ), 3.03 (br s, $18 \mathrm{H}, \mathrm{N}^{+} \mathrm{CH}_{3}$ ), 2.10 (br S, $4 \mathrm{H}, \mathrm{CH}_{2}(1)$ ), 1.52 (br s, $4 \mathrm{H}, \mathrm{CH}_{2}(5)$ ), 1.15 (br m, $8 \mathrm{H}, \mathrm{CH}_{2}(3$ and 4$)$ ) and 0.72 (br s, $4 \mathrm{H}, \mathrm{CH}_{2}(2)$ ), (see Figure S9).

${ }^{13} \mathrm{C}$ NMR (125 MHz, DMSO-d 6 , ppm) Data obtained by HMQC (Figure S10): $\delta=21.9\left(\mathrm{CH}_{2}(2)\right)$, $23.3\left(\mathrm{CH}_{2}(3)\right), 25.5\left(\mathrm{CH}_{2}(4)\right), 28.5\left(\mathrm{CH}_{2}(5)\right), 30.7\left(\mathrm{CH}_{2}(1)\right), 52.0\left(\mathrm{CH}_{3}-\mathrm{N}\right), 65.0\left(\mathrm{CH}_{2}-\mathrm{N}\right), 110.0\left(\mathrm{CH}_{\mathrm{Ar}}\right)$, $1140.4\left(\mathrm{CH}_{\mathrm{Ar}}\right), 118.9\left(\mathrm{CH}_{\mathrm{Ar}}\right), 120.4\left(\mathrm{CH}_{\mathrm{Ar}}\right), 123.1\left(\mathrm{CH}_{\mathrm{Ar}}\right), 125.8\left(\mathrm{CH}_{\mathrm{Ar}}\right), 126.7\left(\mathrm{CH}_{\mathrm{Ar}}\right), 127.3\left(\mathrm{CH}_{\mathrm{Ar}}\right)$, 129.0 $\left(\mathrm{CH}_{\mathrm{Ar}}\right)$ and $130.7\left(\mathrm{CH}_{\mathrm{Ar}}\right)$. (Quaternary carbons were insignificant and negligible detectable signals). IR $\left(\mathrm{KBr}\right.$ disc, $\mathrm{cm}^{-1}$ ): 3405 (broad $+N R_{4}$ ), 3023, 2928, 2855, 1562, 1462, 1400, 1260, 1024, 965, 909, 814, 754,698 and $547 \mathrm{~cm}^{-1}$.

\section{Results and Discussion}

\subsection{Optimization of the Synthesis of PAF and Characterization of the Different Batches}

\subsubsection{General Considerations}

The polymerization batches of the molecular model PAF, via Suzuki coupling, were obtained by using equimolar concentrations of monomers, in a mixture of solvents with $\mathrm{K}_{2} \mathrm{CO}_{3}$, as base, and Aliquat 366, as phase transfer agent (Figure 1). A total amount of 28 batches were synthesized under different conditions. As a standard procedure, the yield and the color of the final product, as well as the molecular weight distribution of the polymers and the RR of their amine groups in the final copolymer were studied. As a summary in general terms, obtained reaction yields were between $34 \%$ and $99 \%$, molecular weights between 3.54 and $36.49 \mathrm{~kg} / \mathrm{mol}$ and degrees of RR between $38 \%$ and $95 \%$. Macroscopically, it was observed that bright yellowish colors usually corresponded to the solids of batches with lower molecular weights or yields, while batches with higher molecular weights or yields showed darker brown colors. All of the polymers were soluble in common organic solvents, such as tetrahydrofuran (THF), chloroform, toluene, and, even, $\mathrm{N}, \mathrm{N}$-dimethylformamide (DMF), with no evidence of aggregation or gel formation.

\subsubsection{Characterization of PAF Batches}

The molecular weight distributions of synthesized polymers were measured by SEC with polystyrene calibration (all collected data is compiled in Figures S11 and S12 of supporting data). In fluorene-based copolymers, SEC analysis overestimate the molecular weights and show multiple well-defined peaks in some batches, possibly due to the formation of different oligomers [34,55].

IR spectra showed identical characteristic peaks that were assignable to stretching vibration $v\left(\mathrm{NH}_{2}\right)$ at 3462 and $3380 \mathrm{~cm}^{-1}$, and corresponding in-plane blending of $(\mathrm{N}-\mathrm{H})$ at $1610 \mathrm{~cm}^{-1}$. They were also found to be very similar to the spectrum of polymer without the amine group, poly[1,4-benzene-co-alt-2,7-(9,9'-dihexylfluorene)] (PBF) (see supplementary information, Figure S13).

In this work, thermal properties, like glass transition $(\mathrm{Tg})$ and decomposition temperature recorded at $5 \%$ mass loss (T5) were studied in order to detect differences among selected batches. PAF $T g$ was around $180 \pm 5^{\circ} \mathrm{C}$ and it was difficult to obtain in a second cycle of heating. $\mathrm{T} 5$ was around $325 \pm 15^{\circ} \mathrm{C}$ in all batches, while the range of mass loss at final temperature $\left(800^{\circ} \mathrm{C}\right.$, inert atmosphere $)$ was $55-65 \%$ (see supporting information, Figure S14).

Absorption and emission spectra of PAF in chloroform solutions from several batches were virtually identical with absorption and emission maximum wavelengths at 360 and $426 \mathrm{~nm}$, respectively (Figure 6A and Table 3). The most significant characteristic of the PAF emission spectra was the absence of a shoulder or second peak, a common event in similar fluorene copolymers, such as PBF. A clear 
red-shift in the emission spectra was observed when changing from chloroform to other solvents, what it will be further described later on in this work.

\subsubsection{Study of the Regioregularity of Synthesized PAF by ${ }^{1} \mathrm{H}-\mathrm{NMR}$}

The presence of an asymmetric amino group in each aniline monomer within the molecular structure of PAF made the study of its RR possible. Depending on the position of the amino groups during the first step of the catalytic cycle (oxidative addition), there can be coupled four types of units or dyads: tail-to-tail (TT), head-to-head (HH), head-to-tail (HT), and tail-to-head (TH). These positions are statistically possible during a growing chain, for further details see supplementary data (Figures S15 and S16).

Coupling bromoanilines with commercial boronate ester of fluorene was previously reported by Yamaguchi et al. [50] who showed ${ }^{1} \mathrm{H}-\mathrm{NMR}$ in $\mathrm{CDCl}_{3}$ data by means of the following models (supplementary data, Figure S17): 1a (3.82 ppm, HH) coupling with 2-bromoaniline; $1 \mathrm{~b}$ (3.85 ppm TT) with 3-bromoaniline and 1c (4.00 ppm for HT or TH) coupling a mixture of 2- and 3-bromoaniline. However, in our spectra, only two groups of $\mathrm{NH}_{2}$ were mostly found when PAF batches were analysed in deuterated chloroform (Figure 2). Assuming Yamaguchi's data, the new assignment of dyads in our polymers was HT or TH structures for chemical shift $\delta$ above $4.10 \mathrm{ppm}$ (area I) and HH/TT for structures below $\delta 4.10 \mathrm{ppm}$ (area II). In Figure 2, the separation between the two areas and their corresponding structures of the dyads, together with the formula that defines RR in this model, are shown.

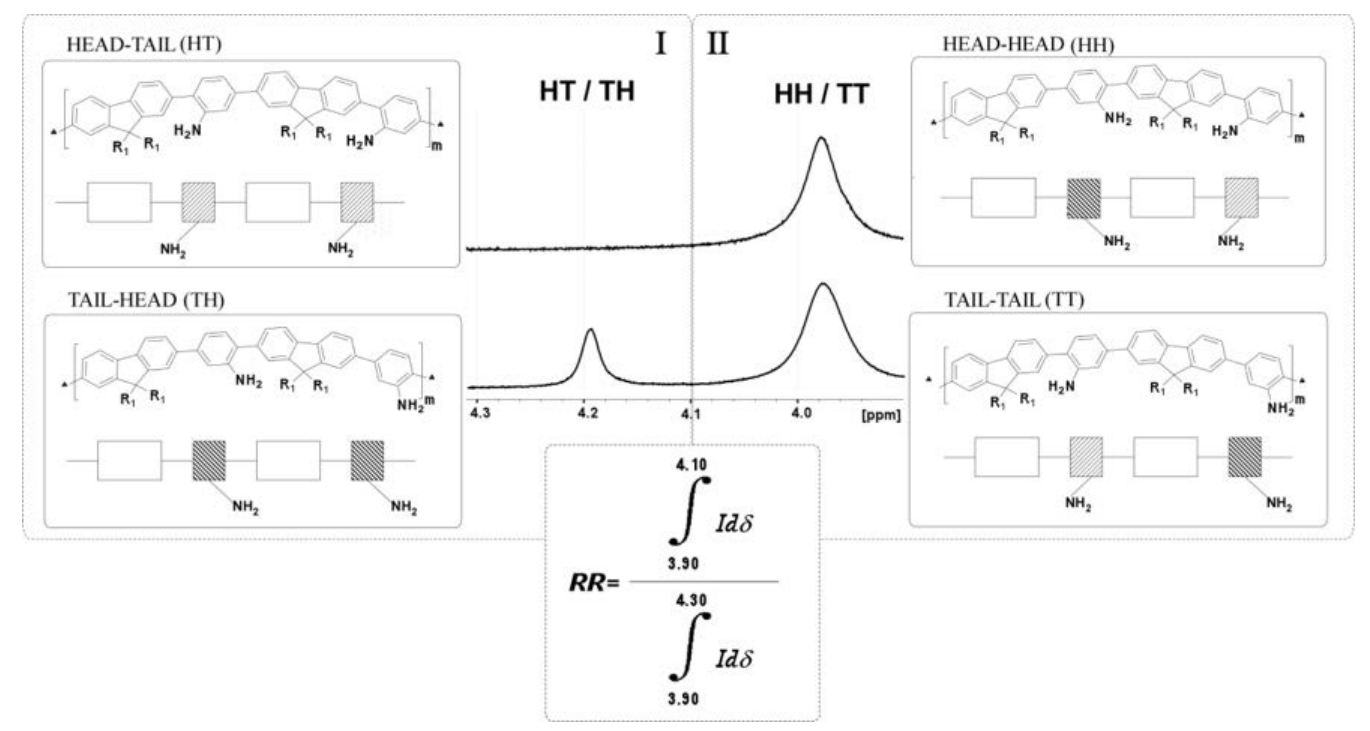

Figure 2. Enlarged region of ${ }^{1} \mathrm{H}-\mathrm{NMR}$ spectra $\left(\mathrm{CDCl}_{3}, 500 \mathrm{MHz}\right)$ corresponding to amine protons areas for two PAFs batches. Four dyads and formula of regioregularity (RR) in this proposed model.

In this work, the RR of each batch was defined and obtained by the integration of the amine protons area II ( $\delta 4.10-3.90 \mathrm{ppm})$ with respect to the total integrated area in amine zone $(\delta 4.3-3.90 \mathrm{ppm})$, followed by its correction with the aliphatic area (at $2 \mathrm{ppm}, 2 \mathrm{x}-\mathrm{CH}_{2}$ - adjacent to $\mathrm{C} 9$ fluorene), taken as reference. Some signals of low intensity that were detected close to these regions were attributed to probable non-completed polymerizations, which might have resulted in low molecular weight polymers, or oligomers and aniline monomers that did not react. The molar percentage ratio of integrated areas between both zones (indicated as \% RR) estimates the number and position of the amine groups within the backbone as well as their assignments that could be used to understand changes in experimental conditions. 
RR percentage might work as an indicator of the preferential orientation of the amine groups in the final polymer. In this study, the values ranged from $38 \%$ to $95 \%$. Percentages of RR $>80 \%$, less content in dyads of TH/HT respect to TT and/or HH dyads (Table 1,\#2,\#3, \#8, and \#9), means that then next coupling prefers again this dyad. In turn, RR percentages from $20 \%$ to $80 \%$ would meet a random process (Table $1, \# 1, \# 4, \# 5, \# 6, \# 7$, and \#10). Lower percentages $(<20 \%)$ with large presence of $\mathrm{TH}$ and/or HT dyads would indicate a preferential block copolymer in the alignment of the amino groups ("hairstyles in the same direction"), this latter case is not found herein.

After synthetic procedures, a selection of representative batches were analysed by ${ }^{1} \mathrm{H}-\mathrm{NMR}$ $(\% \mathrm{RR})$ and SEC $(\mathrm{Mw})$ in order to establish correlations between both factors (see supplementary data Figure S12 and Table S1). For high and low RR, minor variations were found in aromatic and aliphatic proton regions (Figure S1), what it was confirmed by further analysing the structure of PAF by monoand bi-dimensional NMR experiments (Figures S2-S6).

\subsubsection{Synthesis Optimization of PAF}

In order to optimize polymer synthesis conditions, PAF batches that are produced by different procedures have been characterised and compared, paying special attention to the heating sources and catalysts employed. Most reactions under classical conditions were performed at $80^{\circ} \mathrm{C}$, while $\mu \mathrm{W}$ assisted reactions were done at $135^{\circ} \mathrm{C}$. The high temperature achieved in $\mu \mathrm{W}$-assisted procedures give us the opportunity to reduce the reaction time. Therefore, $\mu \mathrm{W}$-assisted heating offers a simple and fast methodology to study and/or optimize the synthesis reactions, which allows for controlling with high precision the conditions of the polymerizations. Furthermore, Suzuki coupling cycle involves intermediate high polar or ionic species, which might be excellent candidates for $\mu \mathrm{W}$ energy transfer in order to obtain good yields [56,57]. Otherwise, although most of the reactions performed under conventional conditions were made using a conventional flask (at atmospheric pressure) and a reflux system, the oil bath reaction was also tested by using a pressure vessel, which allowed for working above the reflux temperature of the solvents and reaching temperatures that were comparable to those attained by $\mu \mathrm{W}$ irradiation. On the other hand, experiments with $\mu \mathrm{W}$-assisted heating were performed here by using two different operational modes, which are provided by the instrument: the dynamic and the solid phase synthesis (SPS). The dynamic mode is an option with standard settings where the power is automatically modulated based on the maximum temperature it can get, while in the SPS mode, the irradiation cycles in bursts are performed by keeping the temperature with a prefixed deviation, $5{ }^{\circ} \mathrm{C}$ usually (see modes in supporting Figure S18).

In general (Table 1), reaction rates were about two orders of magnitude faster by $\mu W$-assisted heating than by conventional heating methods at atmospheric pressure. By performing reactions above boiling temperature, synthesis production was also improved in some aspect in comparison to conventional heating methods. It is remarkable that high yields were obtained in shorter times in most of the batches by $\mu \mathrm{W}$-assisted polymerization (around $20 \mathrm{~min}$ in batches \#6 and \#8, for instance) respect to conventional operation (\#1, \#2). At the same temperature, $135^{\circ} \mathrm{C}$, the use of pressure vessel (\#3) leads to a noticeable yield of polymer with high general properties and without important differences in terms of RR respect to $\mu \mathrm{W}$-assisted heating (\#8), as previously described [58].

Temperature is a critical parameter in a chemical reaction; in this case, the temperature above the boiling point is determinant to accelerate the polymerization process. Furthermore, it looks like there might be a fine equilibrium between the reduction on reaction time and the degradation of some of the species involved in the process. However, polymerizations obtained by increasing the reaction temperature, and, thus accelerating the process, are comparable to longer ones, as observed in a previous work [34].

As indicated in Table 1, SPS operation cycle (\#7, \#8) achieved better results than dynamic mode (\#5, \#6), with excellent yields and good distributions of the polymer Mws (PDI values close to 2), as also noted for polyhomofluorenes irradied with the same $\mu \mathrm{W}$ instrument and similar reaction conditions [30]. For this reason, SPS mode was selected for further $\mu \mathrm{W}$-assisted polymerization studies. 
Table 1. Effect of different heating reaction modes and catalysts on the polymerization of PAF ${ }^{\text {a }}$.

\begin{tabular}{|c|c|c|c|c|c|c|c|c|c|}
\hline \multirow[b]{2}{*}{1} & \multirow[t]{2}{*}{ Catalyst } & \multicolumn{3}{|c|}{ Heating conditions } & \multirow{2}{*}{$\begin{array}{c}\begin{array}{c}\text { Yield } \\
\text { (\%) }\end{array} \\
62\end{array}$} & \multirow{2}{*}{$\begin{array}{c}\begin{array}{c}\mathbf{M w}^{\mathrm{c}} \\
\mathbf{( k g / m o l})\end{array} \\
9.90\end{array}$} & \multirow{2}{*}{$\begin{array}{r}\text { PDI }^{\mathbf{d}} \\
1.9\end{array}$} & \multirow{2}{*}{$\frac{\mathbf{n}^{\mathrm{d}}}{22}$} & \multirow{2}{*}{$\begin{array}{c}\begin{array}{c}\text { \% RR by } \\
\text { NMR }^{\text {e }}\end{array} \\
75\end{array}$} \\
\hline & & Oil bath; & $80 \circ$ & $24 \mathrm{~h}$ & & & & & \\
\hline 2 & \multirow{7}{*}[\mathrm{Pd}(\mathrm{PPh}_{3})_{4}]{} & conventional flask & $80^{\circ} \mathrm{C}$ & $72 \mathrm{~h}$ & 86 & 20.77 & 1.6 & 47 & 87 \\
\hline 3 & & Oil bath; & $125 \circ \mathrm{C}$ & $22 \mathrm{~min}$ & 72 & 6.39 & 2.1 & 14 & 83 \\
\hline 4 & & cressure vessel & $135^{\circ} \mathrm{C}$ & $24 \mathrm{~h}$ & 34 & 3.54 & 1.5 & 8 & 78 \\
\hline 5 & & $\mu \mathrm{W}$ & & $14 \mathrm{~min}$ & 57 & 6.91 & 2.0 & 16 & 70 \\
\hline 6 & & Dynamicmode $^{\mathrm{b}}$ & $135^{\circ} \mathrm{C}$ & $22 \mathrm{~min}$ & 73 & 11.80 & 1.9 & 27 & 74 \\
\hline 7 & & \multirow{4}{*}{$\begin{array}{c}\mu W ; \\
\text { SPS mode }\end{array}$} & \multirow{4}{*}{$135^{\circ} \mathrm{C}$} & $14 \mathrm{~min}$ & 90 & 11.60 & 2.0 & 26 & 73 \\
\hline 8 & & & & $22 \mathrm{~min}$ & 99 & 15.02 & 2.1 & 34 & 94 \\
\hline 9 & {$\left[\operatorname{Pd}(\text { Amphos })_{2} \mathrm{Cl}_{2}\right]$} & & & $14 \mathrm{~min}$ & 71 & 5.43 & 1.9 & 12 & 86 \\
\hline 10 & cis-[ $\left.\mathrm{PdCl}_{2}(\mathrm{dppf})\right]$ & & & $14 \mathrm{~min}$ & 47 & 6.26 & 1.8 & 14 & 64 \\
\hline
\end{tabular}

${ }^{a}$ All polymerizations were carried out with $3 \%$ of catalyst in Toluene $/ \mathrm{H}_{2} \mathrm{O}(2: 1) v / v .{ }^{\mathrm{b}} \mu \mathrm{W}$-assisted reactions were carried out at $150 \mathrm{~W}$ in either Dynamic or solid phase synthesis (SPS) mode, the latest with $\Delta T=5^{\circ} \mathrm{C}$ (see supporting Figure S18). ${ }^{\mathrm{c}} \mathrm{Mw}=$ weight-average molecular weight, estimated by SEC in THF on basis polystyrene calibration. ${ }^{\mathrm{d}}$ PDI (Polydispersity index) $=M w / M n$; where $M n=$ number-average molecular weight, and $\mathrm{n}$ (number of monomer unities) $=\mathrm{Mw} / \mathrm{Mn}$; where $\mathrm{Mu}=$ molecular weight unity $(441.7 \mathrm{~g} / \mathrm{mol}) .{ }^{\text {e }}$ Percentages of regioregularity $(\% \mathrm{RR})$ were calculated in based on ratio NMR to integrated the Area II $(3.9>\delta>4.1 \mathrm{ppm})$ over Total Area $(3.9>\delta>4.3 \mathrm{ppm})$, see Figure 2. Relative error $4 \%$.

Subsequently, a time course of the polymerization procedure was performed by both heating processes (Figure 3). Previous results were confirmed from these assays, showing that conventional heating reaction done at atmospheric pressure is two orders of magnitude slower than the $\mu \mathrm{W}$-assisted one in the SPS mode.
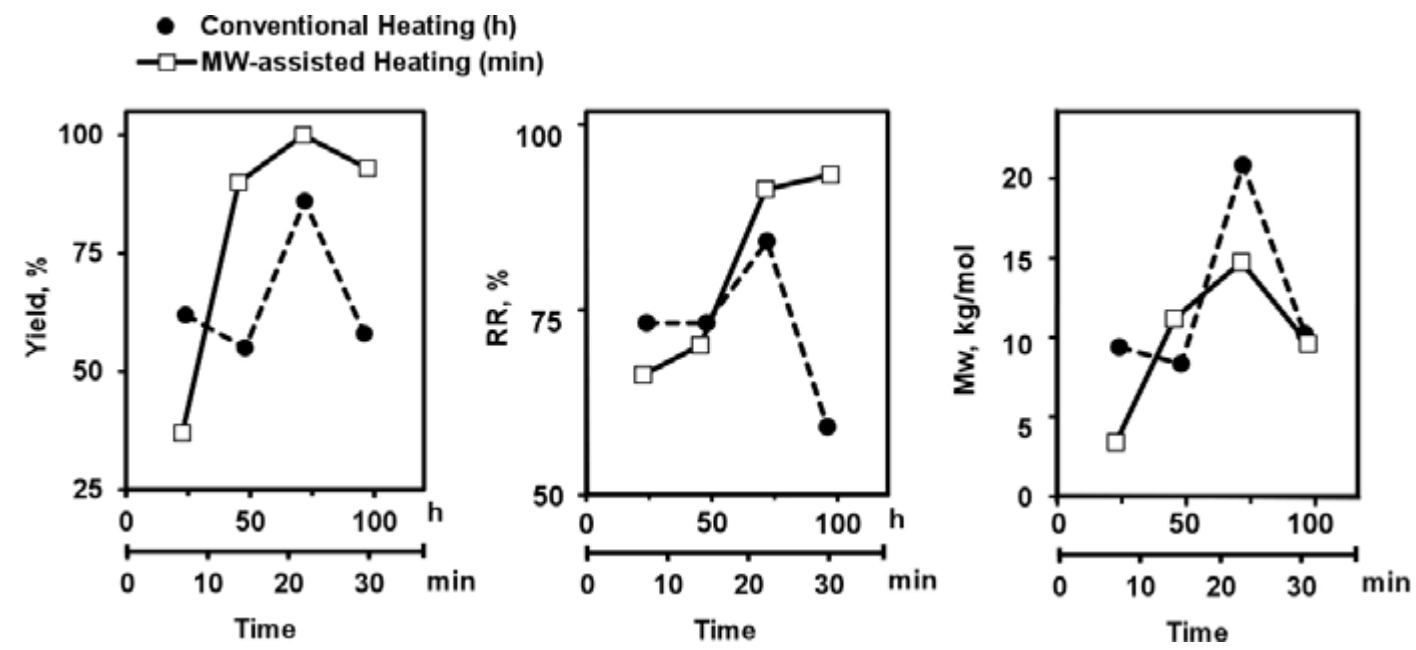

Figure 3. Effect of the time polymerization in microwave-assisted in SPS mode ( $\mu$ W-SPS) (empty squares) and classical heating (filled circles) at different temperatures $\left(135^{\circ} \mathrm{C}\right.$ for $\mu \mathrm{W}$-assisted and $80^{\circ} \mathrm{C}$ for conventional heating) versus percentage of yield (left), regioregularity RR (middle) and weight-average molecular weigth, $\mathrm{Mw}$ (right).

Another parameter, evaluated because of its relevance for synthesis procedures, was the use of different catalysts. In this sense, the best results (in terms of higher yields and $M w$ values), from all tested polymerizations, were achieved for the palladium zero $\left(\left[\mathrm{Pd}\left(\mathrm{PPh}_{3}\right)_{4}\right]\right)$ catalyst in comparison to palladium II ([Pd(Amphos) $\left.{ }_{2} \mathrm{Cl}_{2}\right]$ and cis- $\left.\left[\mathrm{PdCl}_{2}(\mathrm{dppf})\right]\right)$, catalysts that are commonly used in other synthesis models [34]. Therefore, the effect of different concentrations of palladium zero catalyst on both procedures was evaluated. In the first place, a gradient of concentrations of this catalyst was tested in both of the procedures and their final products characterized (Table 2). 
Obtained yields were excelent in all cases (Minimum: 85\% for \#13; Maximum: 100\% for \#14). Mws of final polymers increased with the concentration when using classical heating procedures, but in non-conventional heating it was observed that an optimal result peacked at $3 \%$ of palladium zero (\#7). Regarding RR, in classical heating, the number of coupled dyads TT/HH was substantially greater (\#11,93\%) than in $\mu \mathrm{W}$-assisted heating (\#13, 84\%). It is noticeable that RR tended to decrease with the amount of catalyst, independently of the heating process that is used. Efforts to systematically optimize the $\mu \mathrm{W}$-assisted polymerization conditions to obtain PAF were studied, such as the solvent and volumes employed in the reaction vessels, as well as power and temperature changes in the SPS mode settings (see supplementary data for futher results in Tables S3-S5), were carried out. In general terms, the use of THF instead of toluene produces no differences on the yield but a great effect on the $\mathrm{Mw}$, with a considerable reduction in this value. Furthemore, a power of $150 \mathrm{~W}$ and temperature fluctuation $(\Delta T)$ of $5{ }^{\circ} \mathrm{C}$ seems to be the optimal condition in terms of yield and $M w$.

Table 2. Effect of the concentration of the palladium zero catalyst on the polymerization of PAF.

\begin{tabular}{|c|c|c|c|c|c|c|c|}
\hline$\#$ & Heating Mode & {$\left[\mathrm{Pd}\left(\mathrm{PPh}_{3}\right)_{4}\right](\%)$} & Yield (\%) & $\begin{array}{c}M w^{c} \\
(\mathrm{~kg} / \mathrm{mol})\end{array}$ & PDI $^{d}$ & $n^{\mathrm{d}}$ & $\begin{array}{l}\text { \% RR by } \\
\text { NMR }^{\mathrm{e}}\end{array}$ \\
\hline 11 & & 1 & 90 & 10.70 & 1.9 & 24 & 93 \\
\hline 2 & Oil bath ${ }^{a}$ & 3 & 86 & 20.77 & 1.6 & 47 & 87 \\
\hline 12 & & 6 & 86 & 36.49 & 2.7 & 83 & 86 \\
\hline 13 & & 1 & 85 & 5.73 & 1.7 & 13 & 84 \\
\hline 7 & $\mu \mathrm{W}$ SPS mode ${ }^{b}$ & 3 & 90 & 11.60 & 2.0 & 26 & 72 \\
\hline 14 & & 6 & 100 & 6.45 & 1.6 & 15 & 69 \\
\hline
\end{tabular}

${ }^{a}$ Conventional polymerizations at atmospheric pressure were carried out at $80^{\circ} \mathrm{C}, 72 \mathrm{~h}$; Toluene $/ \mathrm{H}_{2} \mathrm{O}(2: 1) v / v$.

b $\mu \mathrm{W}$-assisted were carried out at $135^{\circ} \mathrm{C}, 14 \mathrm{~min} ; 150 \mathrm{~W}$ and $\Delta T=5^{\circ} \mathrm{C}$; Toluene $/ \mathrm{H}_{2} \mathrm{O}(2: 1) v / v$. ${ }^{\text {c,d,e }}$ Same description on Table 1.

Finally, the effect of the final temperature in the polymerization reaction was also analysed by using SPS mode $\mu \mathrm{W}$-assisted heating (Figure 4, and Table S5).
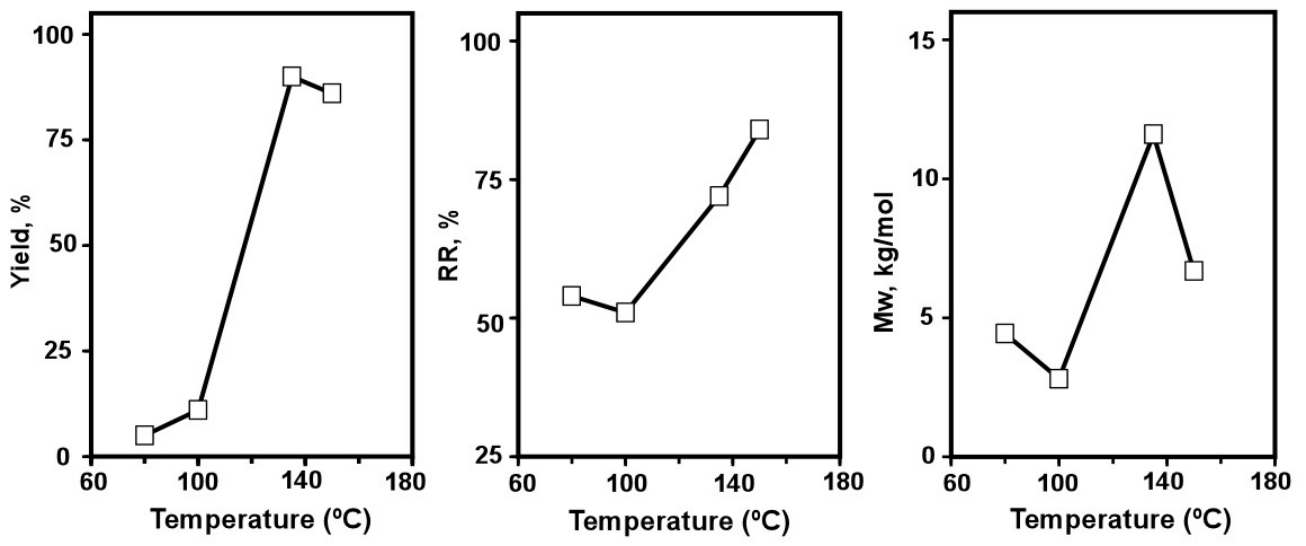

Figure 4. Temperature variation in microwave-assisted polymerizations ( $\mu \mathrm{W}$-SPS) respect to percentage of yield (left), regioregularity RR (middle), and weight-average molecular weigth, Mw (right).

Figure 4 shows the progression of the yields, RR and Mws over temperature until $150{ }^{\circ} \mathrm{C}$, as it has been previuosly reported for homopolyfluorene, at about $150{ }^{\circ} \mathrm{C}$ there was an efficient polymerization with free-defect structures [30]. The optimal temperature for achieving the highest yield and $M w$ values is $135^{\circ} \mathrm{C}$, while the ratio of peaks of amino groups in NMR is high (almost 75\%), but not the highest $\left(84 \%\right.$ at $\left.150^{\circ} \mathrm{C}\right)$. Remarkably, at $150{ }^{\circ} \mathrm{C}$, the yield was similar to that obtained at $135^{\circ} \mathrm{C}$, RR was higher (84\%), but $\mathrm{Mw}$ decreased significantly $(6.68 \mathrm{~kg} / \mathrm{mol}$ respect to $11.60 \mathrm{~kg} / \mathrm{mol}$, value achieved at 
$135^{\circ} \mathrm{C}$ ). Regarding RR, by using this procedure, it was necessary to increase temperature over $100{ }^{\circ} \mathrm{C}$ in order to overcome $50 \%$ RR.

\subsection{Synthesis of a New Cationic Polyelectrolyte (PAFAm)}

To extend the potential applications of PAF to biochemical research, the cationic polyelectrolyte PAFAm was synthesised by transformation of neutral PAFBr. The synthetic route and structure of this polyelectrolyte is also shown in Figure 1. Polymer bromide, PAFBr, was obtained following the optimal conditions established in the previous PAF model ( $\mu \mathrm{W}$-assisted heating in SPS mode). Thus, the polymer was obtained in a $86 \%$ yield, with an average molecular weight of $5825 \mathrm{~g} / \mathrm{mol}(\mathrm{PDI}=2.0)$, as determined by SEC with PS standard. The structure was confirmed by NMR data, with a broad triplet at $3.27 \mathrm{ppm}$ with correspondence with carbon at $32.9 \mathrm{ppm}$ (supplementary Figures S15 and S16).

Quaternization of PAFBr was successfully obtained with total conversion ( $>97 \%)$ and a high purification yield $(80 \%)$ of the new polyelectrolyte (PAFAm), using the treatment with trimethylamine, as previously reported $[53,54]$. Nucleophilic substitution was corroborated by proton and bi-dimensional HMQC NMR in DMSO- $\mathrm{d}_{6}$. Characteristic signals at 3.21 and $3.03 \mathrm{ppm}$, corresponding to $-\mathrm{CH}_{2} \mathrm{~N}^{+}\left(\mathrm{CH}_{3}\right)_{3}$ assignments and their carbons at 52 and $65 \mathrm{ppm},-\mathrm{CH}_{2} \mathrm{~N}^{+}\left(\mathrm{CH}_{3}\right)_{3}$, respectively (supplementary Figures S9 and S10).

Figure 5 shows the IR spectrum of this new precursor polymer, PAFBr, which present the two frequencies of vibration of $v\left(\mathrm{NH}_{2}\right)$ amine groups at 3450 and $3378 \mathrm{~cm}^{-1}$, and a typical band assigned to the alkyl bromide $-\mathrm{CH}_{2} \mathrm{Br}\left(642 \mathrm{~cm}^{-1}\right)$.

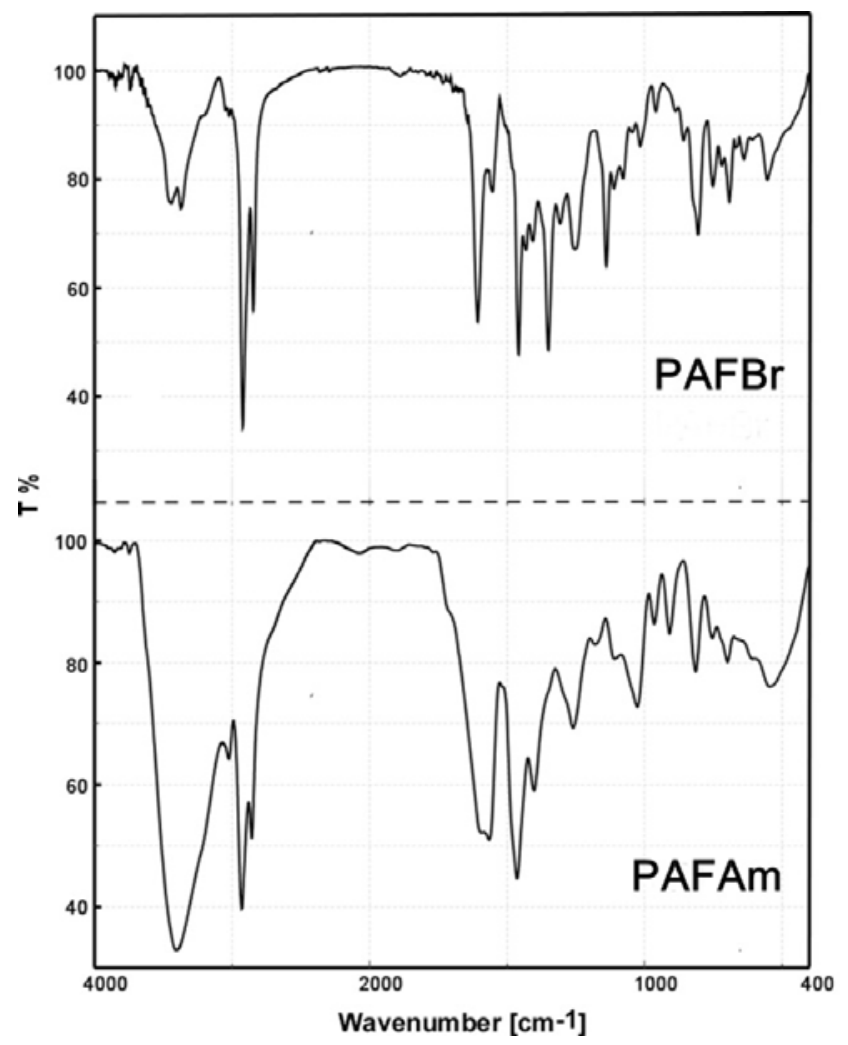

Figure 5. Comparative FT-IR spectra of new polymers synthesized PAFBr and PAFAm, in BrK pellets.

FT-IR spectra of PAFAm (bottom) and PAFBr (top) in BrK pellet was shown in Figure 5, where the disappearance of the band at $642 \mathrm{~cm}^{-1}$ and the appearance of an ammonium band at $3405 \mathrm{~cm}^{-1}$ covering the amine bands, can be observed. In complementary data, Figure S19 shows the electronic absorption and emission spectra of polymers PAFBr in chloroform and PAFAm in water solutions 
performed at room temperature. Both spectra present one maximum absorption at 345 and $352 \mathrm{~nm}$, and their corresponding maximum emission bands, at 431 and $458 \mathrm{~nm}$, respectively, a large Stokes shift ( $\Delta \lambda$ was 86 and $106 \mathrm{~nm}$ PAFBr and PAFAm), evidencing a solvent dependence.

\subsection{Fluorescence Solvatochromism of PAF}

Figure 6A shows red-shift in the emission spectra when changing from chloroform to other solvents, such as THF and DMF, and no increase in the vibronic structure was detected. In THF, the emission peak red-shifted around $20 \mathrm{~nm}$, while in DMF, a shift of $30 \mathrm{~nm}$ was observed respect to chloroform. Absorption and excitation spectra were less sensitive to the solvent change than the emission spectrum, with red-shifts of $6 \mathrm{~nm}$ (THF) and $10 \mathrm{~nm}$ (DMF) respect to the value obtained in chloroform (Figure 6A). Due to the fact that these solvents show different polarity, the above-mentioned behavior suggests the possible existence of dipole-dipole interactions between PAF and solvent molecules [59].

In order to get more insight in this question, the absorption and fluorescence emission spectra of PAF were obtained in other solvents with different polarity. Table 3 shows the absorption and emission data for a constant concentration of PAF $(1 \mu \mathrm{M} ; 0.07-0.04$ a.u. $)$ using eight different solvents. The absorption spectra displayed a weak solvatochromic effect, which suggests a small value for the ground state dipole moment of PAF. In contrast, the emission spectra showed an evident solvent dependence, with a clear bathochromic shift of the fluorescence maximum with increasing solvent polarity. The fact that a much larger solvatochromic effect is observed in the emission, when compared to the absorption spectrum, suggests that the dipole moments of PAF are significantly different between their ground and excited states. The excited state displays a larger dipole moment relative to the ground state, and, consequently, its stabilization is increased in a more polar environment [60].
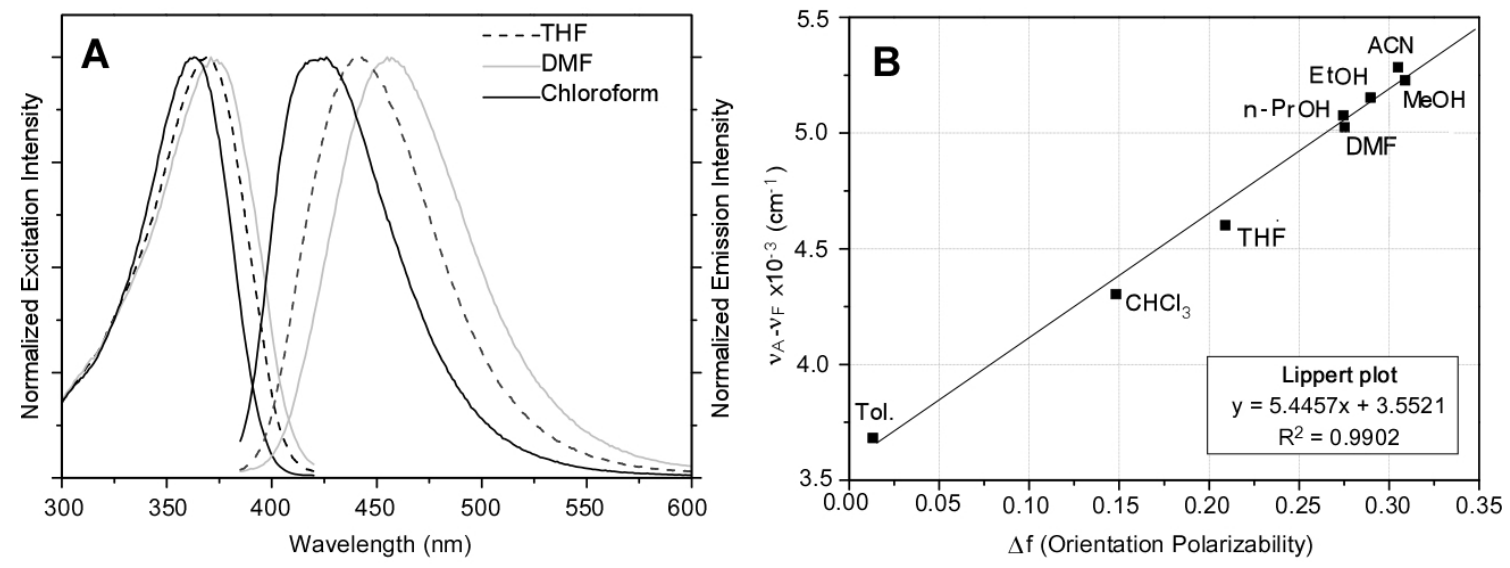

Figure 6. (A) Normalized fluorescence excitation and emission spectra of the same batch of PAF in several solvents (Abs. less 0.05 a.u.): chloroform (solid line), THF (dashed line) and DMF (dotted line). (B) Lippert plot or effect of solvent polarity on the Stokes's shift of PAF.

The fluorescence solvatochromism of PAF was analyzed with the Lippert equation, which relates the Stokes shifts, in $\mathrm{cm}^{-1}\left(\Delta \bar{v}=\bar{v}_{\mathrm{abs}}^{\max }-\bar{v}_{\text {fluo }}^{\max }\right)$, of the fluorophore in different solvents to the orientation polarizability, $\Delta f$ (Table 3). This plot is shown in Figure $6 \mathrm{~B}$ and was reasonably linear, supporting the hypothesis of dipole-dipole interactions between PAF and solvent molecules being mainly responsible for the bathochromic shift. No significant differences were found between protic and non-protic solvents, suggesting that hydrogen bonding of the amine group with the solvent is not responsible for this shift. Table 3 also displays the fluorescence quantum yield of PAF in different solvents. With exception of DMF, a decrease in this value was observed with increasing the polarizability of the solvent, which could suggest that the excited state structure of PAF varies with the solvent [61]. This behavior could be also attributed to the low solubility of PAF in polar solvents and the subsequent 
formation of polymer aggregates, which led to lower emission intensities due to an increase in the interchain energy transport mechanism.

Table 3. Optical properties of PAF in several solvents.

\begin{tabular}{cccccc}
\hline Solvent & $\boldsymbol{\Delta f}^{\mathbf{a}}$ & $\boldsymbol{\lambda}_{\mathbf{A}}{ }^{\max }(\mathbf{n m})$ & $\boldsymbol{\lambda}_{\mathbf{E}}{ }^{\max }(\mathbf{n m})$ & $\boldsymbol{v}_{\mathbf{A}}-\boldsymbol{v}_{\mathbf{E}}\left(\mathbf{c m}^{-\mathbf{1}}\right)$ & $\boldsymbol{\Phi}_{\mathbf{P L}}{ }^{\mathbf{b}}$ \\
\hline Toluene & 0.0132 & 363 & 419 & 3682 & $0.50 \pm 0.05$ \\
Chloroform & 0.1482 & 360 & 426 & 4303 & $0.49 \pm 0.06$ \\
THF & 0.2089 & 366 & 443 & 4601 & $0.55 \pm 0.05$ \\
n-Propanol & 0.2746 & 361 & 442 & 5076 & $0.18 \pm 0.02$ \\
DMF & 0.2754 & 371 & 456 & 5024 & $0.54 \pm 0.03$ \\
Ethanol & 0.2898 & 362 & 445 & 5152 & $0.16 \pm 0.02$ \\
Acetonitrile & 0.3050 & 357 & 440 & 5284 & $0.11 \pm 0.02$ \\
Methanol & 0.3089 & 363 & 448 & 5227 & $0.10 \pm 0.02$ \\
\hline
\end{tabular}

a Polarizability $\Delta f=(\varepsilon-1 / 2 \varepsilon+1)-\left(n^{2}-1 / 2 n^{2}+1\right)$ Lippert equation, where $\varepsilon$ is dielectric constant and $n$ is refractive index using data from Handbook of chemistry and physic [62]. ${ }^{\mathrm{b}}$ Quantum yield was calculated by triplicate probes, comparing the emission to that of a standard solution of quinine sulphate in sulphuric acid $0.1 \mathrm{M}$ $\left(\Phi_{\mathrm{PL}}=0.546\right)$ at $25^{\circ} \mathrm{C}[63]$.

Some commercial solvatochromic fluorophores, such as 2,6-ANS (6-anilinonaphthalene-2sulphonic acid), 1,8-ANS (8-anilinonaphthalene-1-sulphonic acid), Prodan or ADMAN, (6-derivates of 1,2-dimethyaminonaphathelene), exhibit emission properties that are highly sensitive to their immediate environment and have been extensively used for investigating macromolecular interactions, protein conformational changes, or membrane phase transition detection [59]. The solvatochromic properties of PAF, not found in similar fluorene copolymers, could be used to detect this type of biochemical process as well as for other sensing applications.

\section{Conclusions}

In conclusion, we have investigated the $\mu \mathrm{W}$-assisted polymerization via Suzuki coupling of PAF model, which contains alternated aniline and fluorene units. By this methodology, a significant reduction in time was achieved in comparison to classical conditions. This novel and fast methodology gives excelent yields and moderate average Mws (adequate for some applications), and keeps inalterated the physicochemical behaviour of the products. This methodoly has been successfully set-up for obtaining a new cationic polyelectrolyte.

The characterization of the final polymer revealed two interesting features. On one hand, ${ }^{1} \mathrm{H}-\mathrm{NMR}$ data allowed for exploring the asymmetric orientation of the amine groups (regioregularity) in polyfluorenes, establishing a correlation between the assignments of the dyads. Our results suggest that the reaction mechanism has preferences for the activation of a position, thus the high regioregularity found is caused by preferential coupling of TT and/or HH dyads, which will condition the following coupling to go to the same dyad. On the other hand, the PAF model has been found to show a strong non-specific solvatochromic effect, what might be employed as an environmental probe in biochemical applications. This will be the scope of further works.

Supplementary Materials: The following are available online at http://www.mdpi.com/2073-4360/10/20/ 215/s1, which contains experimental details, SEC chromatograms mono- and bi-dimensional NMR spectra and additional figures and tables.

Acknowledgments: This work was supported by the Spanish Ministerio de Economía y Competitividad research projects MAT-2017-86805-R, MAT-2014-53282-R, CTQ2014-53600-R and CTQ2016-76721-R. We also thank the Spanish Ministerio de Educación for the Mobility Fellowship BES-2012-051900.

Author Contributions: C. Reyes Mateo, Ester Vázquez and Ricardo Mallavia conceived and designed the experiments; Rebeca Vázquez-Guilló performed the experiments; Rebeca Vázquez-Guilló, M. José Martínez-Tomé, María Antonia Herrero and Alberto Falco analyzed the data; C. Reyes Mateo, Ester Vázquez and Ricardo Mallavia contributed reagents/materials/analysis tools; Alberto Falco and Ricardo Mallavia wrote the paper.

Conflicts of Interest: The authors declare no conflict of interest. 


\section{References}

1. Bazan, G.C. Novel organic materials through control of multichromophore interactions. J. Org. Chem. 2007, 72, 8615-8635. [CrossRef] [PubMed]

2. Guenes, S.; Neugebauer, H.; Sariciftci, N.S. Conjugated polymer-based organic solar cells. Chem. Rev. 2007, 107, 1324-1338. [CrossRef] [PubMed]

3. Thomas, S.W., III; Joly, G.D.; Swager, T.M. Chemical sensors based on amplifying fluorescent conjugated polymers. Chem. Rev. 2007, 107, 1339-1386. [CrossRef] [PubMed]

4. Hoven, C.V.; Garcia, A.; Bazan, G.C.; Thuc-Quyen, N. Recent applications of conjugated polyelectrolytes in optoelectronic devices. Adv. Mater. 2008, 20, 3793-3810. [CrossRef]

5. Scherf, U.; Gutacker, A.; Koenen, N. All-conjugated block copolymers. Acc. Chem. Res. 2008, 41, $1086-1097$. [CrossRef] [PubMed]

6. Cheng, Y.J.; Yang, S.H.; Hsu, C.S. Synthesis of conjugated polymers for organic solar cell applications. Chem. Rev. 2009, 109, 5868-5923. [CrossRef] [PubMed]

7. Grimsdale, A.C.; Chan, K.L.; Martin, R.E.; Jokisz, P.G.; Holmes, A.B. Synthesis of light-emitting conjugated polymers for applications in electroluminescent devices. Chem. Rev. 2009, 109, 897-1091. [CrossRef] [PubMed]

8. Jiang, H.; Taranekar, P.; Reynolds, J.R.; Schanze, K.S. Conjugated polyelectrolytes: Synthesis, photophysics, and applications. Angew. Chem. Int. Ed. 2009, 48, 4300-4316. [CrossRef] [PubMed]

9. Tapia, M.J.; Montserin, M.; Valente, A.J.; Burrows, H.D.; Mallavia, R. Binding of polynucleotides to conjugated polyelectrolytes and its applications in sensing. Adv. Colloid Interface Sci. 2010, 158, 94-107. [CrossRef] [PubMed]

10. Singh, T.B.; Sariciftci, N.S.; Grote, J.G. Bio-organic optoelectronic devices using DNA. Org. Electron. 2010, 223, 189-212.

11. Duarte, A.; Pu, K.-Y.; Liu, B.; Bazan, G.C. Recent advances in conjugated polyelectrolytes for emerging optoelectronic applications. Chem. Mater. 2011, 23, 501-515. [CrossRef]

12. Bian, L.Y.; Zhu, E.W.; Tang, J.; Tang, W.H.; Zhang, F.J. Recent progress in the design of narrow bandgap conjugated polymers for high-efficiency organic solar cells. Prog. Polym. Sci. 2012, 37, 1292-1331. [CrossRef]

13. Zhu, C.; Liu, L.; Yang, Q.; Lv, F.; Wang, S. Water-soluble conjugated polymers for imaging, diagnosis, and therapy. Chem. Rev. 2012, 112, 4687-4735. [CrossRef] [PubMed]

14. Feng, L.; Zhu, C.; Yuan, H.; Liu, L.; Lv, F.; Wang, S. Conjugated polymer nanoparticles: Preparation, properties, functionalization and biological applications. Chem. Soc. Rev. 2013, 42, 6620-6633. [CrossRef] [PubMed]

15. Guo, X.; Baumgarten, M.; Mullen, K. Designing pi-conjugated polymers for organic electronics. Prog. Polym. Sci. 2013, 38, 1832-1908. [CrossRef]

16. Rochat, S.; Swager, T.M. Conjugated amplifying polymers for optical sensing applications. ACS Appl. Mater. Interfaces 2013, 5, 4488-4502. [CrossRef] [PubMed]

17. Blayney, A.J.; Perepichka, I.F.; Wudl, F.; Perepichka, D.F. Advances and challenges in the synthesis of poly(p-phenylene vinylene)-based polymers. Isr. J. Chem. 2014, 54, 674-688. [CrossRef]

18. Li, K.; Liu, B. Polymer-encapsulated organic nanoparticles for fluorescence and photoacoustic imaging. Chem. Soc. Rev. 2014, 43, 6570-6597. [CrossRef] [PubMed]

19. Cho, S.Y.; Grimsdale, A.C.; Jones, D.J.; Watkins, S.E.; Holmes, A.B. Polyfluorenes without monoalkylfluorene defects. J. Am. Chem. Soc. 2007, 129, 11910-11911. [CrossRef] [PubMed]

20. Schluter, A.D. The tenth anniversary of suzuki polycondensation (spc). J. Polym. Sci. A 2001, 39, $1533-1556$. [CrossRef]

21. Sakamoto, J.; Rehahn, M.; Wegner, G.; Schlueter, A.D. Suzuki polycondensation: Polyarylenes a la carte. Macromol. Rapid Commun. 2009, 30, 653-687. [CrossRef] [PubMed]

22. Paul, S.; Islam, M.M.; Islam, S.M. Suzuki-miyaura reaction by heterogeneously supported pd in water: Recent studies. RSC Adv. 2015, 5, 42193-42221. [CrossRef]

23. Scherf, U.; List, E.J.W. Semiconducting polyfluorenes-Towards reliable structure-property relationships. Adv. Mater. 2002, 14, 477-487. [CrossRef]

24. Becker, K.; Scherf, U.; Neher, D. Polyfluorenes; Springer: Berlin, Germmany, 2008.

25. Xie, L.H.; Yin, C.R.; Lai, W.Y.; Fan, Q.L.; Huang, W. Polyfluorene-based semiconductors combined with various periodic table elements for organic electronics. Prog. Polym. Sci. 2012, 37, 1192-1264. [CrossRef] 
26. Kowalski, S.; Allard, S.; Zilberberg, K.; Riedl, T.; Scherf, U. Direct arylation polycondensation as simplified alternative for the synthesis of conjugated (co)polymers. Prog. Polym. Sci. 2013, 38, 1805-1814. [CrossRef]

27. Mercier, L.G.; Leclerc, M. Direct (hetero)arylation: A new tool for polymer chemists. Acc. Chem. Res. 2013, 46, 1597-1605. [CrossRef] [PubMed]

28. Rudenko, A.E.; Thompson, B.C. Optimization of direct arylation polymerization (DARP) through the identification and control of defects in polymer structure. J. Polym. Sci. A 2015, 53, 135-147. [CrossRef]

29. Morin, P.O.; Bura, T.; Sun, B.; Gorelsky, S.I.; Li, Y.N.; Leclerc, M. Conjugated polymers a la carte from time-controlled direct (hetero)arylation polymerization. ACS Macro Lett. 2015, 4, 21-24. [CrossRef]

30. Zhang, W.; Lu, P.; Wang, Z.; Ma, Y. Microwave-assisted suzuki coupling reaction for rapid synthesis of conjugated polymerpoly(9,9-dihexylfluorene)s as an example. J. Polym. Sci. A 2013, 51, 1950-1955. [CrossRef]

31. Gao, X.; Lu, P.; Ma, Y. Ultrasound-assisted suzuki coupling reaction for rapid synthesis of polydihexylfluorene. Polymer 2014, 55, 3083-3086. [CrossRef]

32. Zhang, W.; Wang, Z.; Zhang, Y.; Lu, P.; Liu, L.; Ma, Y. Microwave-assisted $\mathrm{FeCl}_{3}$-mediated rapid synthesis of poly(9,9-dihexylfluorene) with high molecular weight. Polymer 2014, 55, 5346-5349. [CrossRef]

33. Mallavia, R.; Montilla, F.; Pastor, I.; Velasquez, P.; Arredondo, B.; Alvarez, A.L.; Mateo, C.R. Characterization and side chain manipulation in violet-blue poly-(9,9-dialkylfluoren-2,7-diyl)-alt-co-(benzen-1,4-diyl) backbones. Macromolecules 2005, 38, 3185-3192. [CrossRef]

34. Molina, R.; Gomez-Ruiz, S.; Montilla, F.; Salinas-Castillo, A.; Fernandez-Arroyo, S.; del Mar Ramos, M.; Micol, V.; Mallavia, R. Progress in the synthesis of poly(2,7-fluorene-alt-1,4-phenylene), pfp, via suzuki coupling. Macromolecules 2009, 42, 5471-5477. [CrossRef]

35. Knaapila, M.; Lyons, B.P.; Hase, T.P.A.; Pearson, C.; Petty, M.C.; Bouchenoire, L.; Thompson, P.; Serimaa, R.; Torkkeli, M.; Monkman, A.P. Influence of molecular weight on the surface morphology of aligned, branched side-chain polyfluorene. Adv. Funct. Mater. 2005, 15, 1517-1522. [CrossRef]

36. Abbel, R.; Schenning, A.; Meijer, E.W. Molecular weight optimum in the mesoscopic order of chiral fluorene (co)polymer films. Macromolecules 2008, 41, 7497-7504. [CrossRef]

37. Murage, J.; Eddy, J.W.; Zimbalist, J.R.; McIntyre, T.B.; Wagner, Z.R.; Goodson, F.E. Effect of reaction parameters on the molecular weights of polymers formed in a suzuki polycondensation. Macromolecules 2008, 41, 7330-7338. [CrossRef]

38. Zhao, X.Y.; Jiang, H.; Schanze, K.S. Polymer chain length dependence of amplified fluorescence quenching in conjugated polyelectrolytes. Macromolecules 2008, 41, 3422-3428. [CrossRef]

39. Knaapila, M.; Monkman, A.P. Methods for controlling structure and photophysical properties in polyfluorene solutions and gels. Adv. Mater. 2013, 25, 1090-1108. [CrossRef] [PubMed]

40. Kappe, C.O. Controlled microwave heating in modern organic synthesis. Angew. Chem. Int. Ed. 2004, 43, 6250-6284. [CrossRef] [PubMed]

41. Lidström, P.; Tierney, J.; Wathey, B.; Westman, J. Microwave assisted organic synthesis-A review. Tetrahedron 2001, 57, 9225-9283. [CrossRef]

42. De la Hoz, A.; Diaz-Ortiz, A.; Moreno, A. Microwaves in organic synthesis. Thermal and non-thermal microwave effects. Chem. Soc. Rev. 2005, 34, 164-178. [CrossRef] [PubMed]

43. Dallinger, D.; Kappe, C.O. Microwave-assisted synthesis in water as solvent. Chem. Rev. 2007, 107, $2563-2591$. [CrossRef] [PubMed]

44. Wiesbrock, F.; Hoogenboom, R.; Schubert, U.S. Microwave-assisted polymer synthesis: State-of-the-art and future perspectives. Macromol. Rapid Commun. 2004, 25, 1739-1764. [CrossRef]

45. Kappe, C.O.; Dallinger, D. The impact of microwave synthesis on drug discovery. Nat. Rev. Drug Discov. 2006, 5, 51-63. [CrossRef] [PubMed]

46. Roberts, B.A.; Strauss, C.R. Toward rapid,"green”, predictable microwave-assisted synthesis. Acc. Chem. Res. 2005, 38, 653-661. [CrossRef] [PubMed]

47. Galbrecht, F.; Buennagel, T.W.; Scherf, U.; Farrell, T. Microwave-assisted preparation of semiconducting polymers. Macromol. Rapid Commun. 2007, 28, 387-394. [CrossRef]

48. Hoogenboom, R.; Schubert, U.S. Microwave-assisted polymer synthesis: Recent developments in a rapidly expanding field of research. Macromol. Rapid Commun. 2007, 28, 368-386. [CrossRef]

49. Ebner, C.; Bodner, T.; Stelzer, F.; Wiesbrock, F. One decade of microwave-assisted polymerizations: Quo vadis? Macromol. Rapid Commun. 2011, 32, 254-288. [CrossRef] [PubMed] 
50. Yamaguchi, I.; Mizoguchi, N.; Sato, M. Self-doped polyphenylenes containing electron-accepting viologen side group. Macromolecules 2009, 42, 4416-4425. [CrossRef]

51. Chen, T.A.; Wu, X.M.; Rieke, R.D. Regiocontrolled synthesis of poly(3-alkylthiophenes) mediated by rieke zinc-Their characterization and solid-state properties. J. Am. Chem. Soc. 1995, 117, 233-244. [CrossRef]

52. Yamaguchi, I.; Makishi, S. Synthesis and chemical properties of electrochromic-conjugated polyphenylenes with pendant viologen-tenq salts. J. Appl. Polym. Sci. 2013, 129, 397-403. [CrossRef]

53. Liu, B.; Bazan, G.C. Synthesis of cationic conjugated polymers for use in label-free DNA microarrays. Nat. Protoc. 2006, 1, 1698-1702. [CrossRef] [PubMed]

54. Mallavia, R.; Martinez-Perez, D.; Chmelka, B.F.; Bazan, G.C. Blue fluorescent films based on poly-2,7fluorene-phenylene derivatives. Bol. Soc. Española Cerám. Vidrio 2004, 43, 327-330. [CrossRef]

55. Klaerner, G.; Miller, R.D. Polyfluorene derivatives: Effective conjugation lengths from well-defined oligomers. Macromolecules 1998, 31, 2007-2009. [CrossRef]

56. Kappe, C.O. Microwave dielectric heating in synthetic organic chemistry. Chem. Soc. Rev. 2008, 37, 1127-1139. [CrossRef] [PubMed]

57. Qing Han, L.; Yong, D.; Gang, Z.; Zhen, Z.; Song, M. Suzuki-miyaura cross-coupling reaction catalyzed by supported palladium under microwave irradiation. Curr. Org. Synth. 2017, 14, 462-476.

58. Herrero, M.A.; Kremsner, J.M.; Kappe, C.O. Nonthermal microwave effects revisited: On the importance of internal temperature monitoring and agitation in microwave chemistry. J. Org. Chem. 2008, 73, 36-47. [CrossRef] [PubMed]

59. Lakowicz, J.R. Principles of Fluorescence Spectroscopy, 2nd ed.; Kluwer Academic/Plenum: New York, NY, USA, 1999; p xxiii 698.

60. Pina, J.; de Melo, J.S.; Breusov, D.; Scherf, U. Donor-acceptor-donor thienyl/bithienyl-benzothiadiazole/ quinoxaline model oligomers: Experimental and theoretical studies. Phys. Chem. 2013, 15, 15204-15213. [CrossRef] [PubMed]

61. Ooyama, Y.; Ito, G.; Kushimoto, K.; Komaguchi, K.; Imae, I.; Harima, Y. Synthesis and fluorescence and electrochemical properties of d-pi-a structural isomers of benzofuro[2,3-c]oxazolo[4,5-a]carbazole-type and benzofuro[2,3-c]oxazolo[5,4-a]carbazole-type fluorescent dyes. Org. Biomol. Chem. 2010, 8, 2756-2770. [CrossRef] [PubMed]

62. Lide, D.R. Handbook of Chemistry and Physics; CRCPress: Boca Raton, FL, USA, 1999.

63. Melhuish, W.H. Quantum efficiencies of fluorescence of organic substances-effect of solvent and concentration of fluorescent solute. J. Phys. Chem. 1961, 65, 229-235. [CrossRef] 